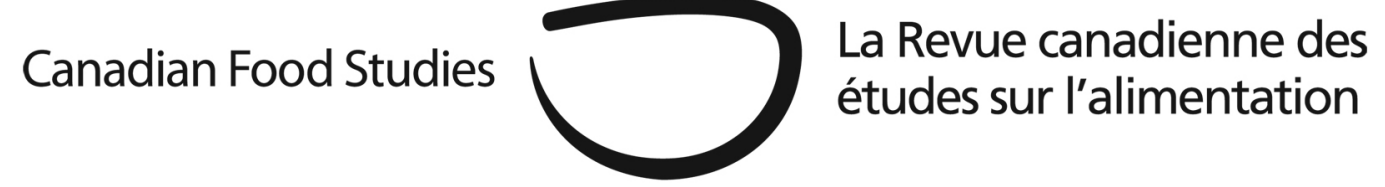

Section VI

Genetic resources and agricultural biotechnology

Special Issue: Mapping the Global Food Landscape

\title{
GMO 2.0: Genetically modified crops and the push for Africa's green revolution
}

\author{
Matthew A. Schnurr \\ Associate Professor, Department of International Development Studies, Dalhousie University
}

Genetically modified (GM) crops are plants in which the DNA has been engineered using laboratory techniques to express a beneficial trait. Their reception across the globe has been mixed: they form a dominant part of North American agriculture, they have been met with widespread disapproval in Europe, and they are of increasing importance in emerging economies such as India, China and Brazil. Approximately 9 percent of agricultural land worldwide was planted under GM crops in 2014. This figure expanded at a rate of 6 million hectares over the previous year, driven largely by growth in the Global South. Developing countries now account for more than 50 percent of the total acreage planted worldwide, and more than 90 percent of the 18 million farmers cultivating them (James, 2014).

This first wave of GM crops was focused around herbicide and pest-resistance, designed to make industrial farming more productive and more profitable. Over the past decade, a second wave of GM crops has emerged, one with a substantive focus on improving yields and livelihoods and a geographical focus on developing countries. Supporters suggest that these second-generation GM crops-which I refer to here as GMO 2.0-present a new vision for the contribution agricultural biotechnology can make to the global food system.

Africa in particular has emerged as the "final frontier" in the global debate over GM agriculture, and a key component of the broader push towards Africa’s Green Revolution (Karembu, Nguthi, \& Abdel-Hamid, 2009). The debate over the potential for GM crops to transform African agriculture is an important test for proponents who claim that agricultural biotechnology can play a crucial role in alleviating poverty and hunger. This paper aims to 
survey the current state of GMO 2.0 in Africa and identify the key trends, critiques and questions that are shaping this contentious debate.

\section{Trends: What does GMO 2.0 look like?}

Across Africa, the most important actors supporting this push towards GM crops are philanthropic foundations (especially Rockefeller and Gates), and bilateral development agencies (especially USAID). This politico-philanthropic-corporate alliance, as McMichael and Schneider (2011) refer to it, laments that Africa was bypassed by the first Green Revolution, arguing that a massive investment in technologies such as hybrid seeds, fertilizers, pesticides and genetic modification is needed to improve yields and livelihoods throughout the continent. The major turning point in these efforts was the establishment of the Alliance for a Green Revolution in Africa (AGRA) in 2006, which has directly channeled more than US\$400 million to agricultural improvement efforts as part of a broader package of infrastructure, capacity building, and experimentation (AGRA, 2014).

GM has emerged as a key element of this vision for a uniquely African Green Revolution. Its advancement has been propelled not by multi-national corporations who own the proprietary rights to these technologies, but by new agents, funded primarily by foundations and development donors, such as the African Agricultural Technology Foundation (AATF), Program for Biosafety Systems (PBS), and Agricultural Biosafety Support Project (ABSP). These intermediaries play an integral role in facilitating GM's expansion across the continent: they enable access to proprietary technology, they channel funds to construct the significant infrastructure needed for domestic experimentation, they fund the training of hundreds of scientists to build capacity in the areas of research and regulation, and they engineer campaigns of “demystification" and "sensitization” designed to cultivate domestic support for GM. The result is a coordinated, comprehensive strategy that operates largely from the outside in (Schnurr, 2013).

Over the past ten years there has been a concerted shift to diversify the crops and traits under experimentation in order to prioritize those that matter to poor farmers. In Africa, this push is focused on carbohydrate staples that have been largely ignored by previous efforts at investment and improvement, including cassava, cowpea, sorghum, and cooking banana. The traits that are being prioritized are those that are deemed most relevant for vulnerable farmers, such as drought-resistance, bio-fortification, and resistance to local pests and diseases.

Experimental programs have proliferated across the continent, including Nutritionally Enhanced Sorghum in Kenya, Disease-Resistant Cooking Banana in Uganda, and InsectResistant Cowpea in West Africa. Each of initiatives follows a similar template. These are Public-Private Partnerships (PPPs), facilitated by intermediaries, in which the technology is given royalty-free to experimental programs undertaken by African scientists employed by government ministries. This arrangement, proponents argue, mitigates concerns over intellectual 
property and the expanding influence of multi-national corporations. The result, though, is that critical decisions over the direction and focus of each PPP remains almost exclusively within the purview of these powerful actors, with few opportunities for farmers to shape and influence these experimental programs.

Two examples illustrate how these agents come together to create experimental programs designed to address the needs of smallholder farmers. One of the most heralded is Water Efficient Maize for Africa (WEMA). Started in 2008, this initiative "was created with a goal to enhance food security in Sub-Saharan Africa through developing and deploying drought-tolerant maize royalty-free to the smallholder farmer... This increased yield stability has the potential to help reduce hunger and improve the livelihood of millions of Africans” (Monsanto, 2014a). This partnership is coordinated by the AATF and funded primarily by the Bill and Melinda Gates Foundation (with support from the Buffett Foundation and USAID). It utilizes Monsanto's proprietary technology (donated license-free on humanitarian grounds), which inserts this into local maize varieties with the aim of helping over ten million farmers across five countries throughout east and southern Africa. Initial trials suggest that these transgenic drought-resistant varieties have yields that are more than 20 percent higher than regular hybrids (Oikeh et al., 2014, p. 320).

A second flagship experimental program revolves around virus-resistant cassava. Designed to increase resistance to two of the most pernicious viruses affecting cassava (cassava mosaic disease and brown streak disease) this PPP brings together the Monsanto Fund, Gates Foundation, and the International Institute for Tropical Agriculture (IITA). Spearheaded by the Danforth Institute, this program is optimistic it can achieve commercialization by 2015 (Monsanto, 2014b).

\section{Challenges and Critiques: Is GMO 2.0 really a reboot?}

The first challenge presented by the new relationships and new traits that underpin GMO 2.0 is the complex web of actors who are promoting these technologies. Much of the conversation within Africa revolves around the need for science-based evidence. But the current dialogue insufficiently recognizes the degree to which science and politics are inextricably interwoven in propelling this particular vision of agricultural development. ${ }^{1}$ The challenge here is to unravel the complex networks of development donors, philanthropic foundations, and multi-national corporations that underpin this new paradigm in order to better understand their motivations,

\footnotetext{
${ }^{1}$ One striking example of the impossibility of teasing apart the scientific from the political is the recent announcement that the Bill and Melinda Gates Foundation has donated US \$5.6 million to Cornell University to promote a 'science-based debate' around GM crops in Africa. The lead representative of this program describes the initiative in the following terms: "Our goal is to depolarize the GMO debate and engage with potential partners who may share common values around poverty reduction and sustainable agriculture, but may not be well informed about the potential biotechnology has for solving major agricultural challenges” (Shackford, 2014).
} 
intentions and aspirations. This process leads to some sticky questions around why GM is being advanced as the preferred technological solution for African farmers, and the potential benefits for those who are seeking GM’s entry into Africa (Schnurr, 2013).

A second line of critique concerns biosafety. A comprehensive, legislated regulatory regime that conforms international protocols on environment and food safety is a precondition for the release of GM technology in Africa: none of the companies donating their proprietary technology are willing to operate in countries without one. As such, the governance and regulation of GM crops has emerged as a critical dimension of this debate over the potential for GM crops to transform African agriculture. The domestic frameworks that have emerged over the past ten years tend to follow a similar blueprint, based on a permissive model that emerged from building blocks provided by UNEP's Global Environment Facility in the 1990s. More recently, the focus has shifted towards super-national regulatory efforts at both continental (e.g. African Union) and regional levels (e.g. East African Community, Common Market for Eastern and Southern Africa). The ultimate aspiration is a harmonized system that could implement a centralized and standardized assessment mechanism, whereby an application that is vetted, tested and approved in one African country could be approved in another without additional delay.

Critics argue that this results in a one-size-fits-all formula whereby heavy investment in infrastructure and capacity building create a regulatory regime that is largely sympathetic to GM technology. For example, a recent analysis of the evolution of the regulatory process in Uganda uncovered extensive overlap between the individuals and institutions responsible for promoting and regulating biotechnology. The result is a system of governance in which those invested in the technology's success are also the ones making the critical decisions around oversight and accountability (Schnurr \& Gore, 2015). Proponents argue that what is most urgently needed to improve existing regulatory structures is the "political will” to ensure the safe handling and consumption of GM technology (Wambungu \& Kamanga, 2014). But the Ugandan case suggests that the deeper challenge is separating out the tasks of promotion and regulation given the limited domestic capacity that exists in most African countries.

One final challenge is the broader issue of whether GMO 2.0 represents a continuation of technocratic development that has characterized the past fifty years of agricultural interventions in Africa. An examination of trends within the promotion and regulation of GM suggest that the push towards biotechnology still operates largely from the outside in. Within this formulation it is the solution (GM crops) that comes before the problem (improving yields and livelihoods for African farmers). This inverted starting point narrows the debate over Africa's agricultural future to one that is focused solely on new technologies, and ignores other pressing issues such as crop diversification, land reform to increase access for smallholder farmers, access to extension workers, transport issues, water availability, access to credit and storage capacity. 


\section{Questions for moving forward}

One of the most important and under-researched questions within this debate revolves around the intended end users: how will these second-generation GM crops be received by African farmers? Many individuals and interests are speaking on behalf of farmers, but few are listening (Schnurr \& Mujabi-Mujuzi, 2014; Stone \& Flachs, 2014). No one is really sure whether these technologies make sense given the ecological, economic and social conditions farmers face across the continent.

The issue of scale is crucial here. The debate needs to shift away from macro conversations about GM's suitability in Africa to more micro questions around whether GM constitutes an appropriate technology, given the particular conditions that farmers encounter on the ground. Further, we need more research investigating whether the second wave of GM crops currently under experimentation are scale-neutral. Previous research on first-generation GM crops already released in Africa show that larger, wealthier farmers tend to benefit disproportionately from these technologies (Morse \& Mannion, 2009; Witt, Patel, \& Schnurr, 2006). Will these new genetically modified traits/crops benefit small-scale producers? Currently there is a dearth of ex ante studies that examine the potential impacts of GM crops given the varied realities facing farmers across the continent.

Another important question revolves around the implications of emerging breeding technologies, which further complicate debates over the potential for GM crops to help African farmers. While defining genetic modification has always been contested, the consensus since the 1990s is that modern agricultural biotechnology is defined by the creation of transgenic material (e.g. taking genetic material from one organism and transferring it into the genetic code of another). New technologies are emerging that are challenging this static definition, including advanced genetic manipulation technologies that allow high-precision editing of the plant's own genome via cisgenesis (in which only genes from the same species are introduced) or targeted mutagenesis (in which only specific nucleotides in a gene are changed) or gene silencing (in which a particular gene is turned off). Advances in synthetic biology —in which genetic engineering techniques are used to mimic, accelerate or improve existing biological systemspresent a whole new array of breeding possibilities. Many of these new breeding technologies leave the resultant crop free of genes foreign to the species, thus complicating many of the wellworn ethical dimensions of this debate. More research is needed to understand the potential applications and implications of this fast-changing technological frontier.

These debates also create pressing questions for donors. For instance, Canadian development agencies have a long history of investing in agricultural technology as a key component of its overseas development assistance. Both the Department of Foreign Affairs, Trade, and Development (DFATD) and the International Development Research Council (IDRC) view GM as a “productivity enhancement solution”, and continue to invest in exploring its possibilities as a tool for agricultural development via the Canadian International Food Security Research Fund, the Bioscience Centre for East and Central Africa and the newly launched 
Cultivate Africa's Future Project (DFATD 2013; IDRC 2013). This narrow focus on technologydriven development tends to situate hunger as a technical rather than a political problem, and fails to question some of the assumptions that underpin the enthusiasm for GM, including the degree to which this model of development is driven by outside interests, the role of the private sector in agricultural development, as well as deeper questions around whether GM crops constitute an appropriate technology for African farmers.

Perhaps the most important question is the one we need to move beyond: the reductive proposition that everything and everyone is either pro- or anti-GMO. Much of the conversation in research and policy circles still hinges on an all-or-nothing approach to Africa's future with genetically modified crops. New organizations are proliferating on both sides of the debate, adding yet another voice to their camp in the hopes of swaying momentum to their side. Researchers and policy-makers need to move beyond this bifurcated debate, to ask more nuanced questions about whether this particular GM crop or trait makes sense given the specific ecological, economic and cultural circumstances facing a particular African farmer.

\section{References}

Alliance for a Green Revolution in Africa (AGRA). (2014). AGRA in 2013: Transforming African agriculture through partnerships. Nairobi, Kenya: Alliance for a Green Revolution in Africa (AGRA).

Department of Foreign Affairs, Trade and Development (DFATD). (2013). Project profile: Association for Strengthening Agricultural Research in Eastern and Central Africa - I. Retrieved from http://www.acdicida.gc.ca/cidaweb/cpo.nsf/vWebCSAZEn/4B21AFB3BD8B3FFF85257C6B003E18DA

International Development Research Council (IDRC). (2013). Reducing poverty and improving food security through small-scale agriculture. Retrieved from http://www.idrc.ca/EN/Programs/Agriculture_and_the_Environment/Agriculture_and_Foo d_Security/Pages/default.aspx

James, C. (2014). Global status of commercialized biotech/GM crops: 2014. (ISAAA Brief No. 49). ISAAA: Ithaca, NY.

Karembu, M., Nguthi, F., \& Abdel-Hamid, I. (2009). Biotech crops in Africa: The final frontier. ISAAA AfriCenter: Nairobi, Kenya. 
McMichael, P., \& Schneider, M. (2011). Food security politics and the Millennium Development Goals. Third World Quarterly, 32(1), 119-139.

Monsanto. (2014a). Water efficient maize for Africa: Improved maize varieties to aid farmers in Africa. Retrieved from http://www.monsanto.com/improvingagriculture/pages/waterefficient-maize-for-africa.aspx

Monsanto. (2014b). Virus resistant cassava for Africa (VIRCA). Retrieved from http://www.monsanto.com/improvingagriculture/pages/virus-resistant-cassava-forafrica.aspx

Morse, S., \& Mannion, A.M. (2009). Can genetically modified cotton contribute to sustainable development in Africa? Progress in Development Studies, 9(3), 225-247.

Oikeh, S., Ngonyamo-Majee, D., Mugo, S.I.N., Mashingaidze, K., Cook, V., \& and M. Stephens. (2014). The water efficient maize for Africa project as an example of a PublicPrivate-Partnership. In, D.D. Songstad, J. Hatfield, \& D. Tomes, (Eds.), Convergence of food security, energy security and sustainable agriculture (pp. 317-329). Berlin: Springer.

Schnurr, M.A. (2013). Bio-hegemony and biotechnology in Uganda: Unraveling the strategies used to promote Genetically Modified crops into new African market. Journal of Peasant Studies, 40(4), 639-658.

Schnurr, M.A., \& Gore, C. (2015). Getting to ‘yes’: Governing genetically modified crops in Uganda. Journal of International Development, 27, 55-72.

Schnurr, M.A., \& Mujabi-Mujuzi, S. (2014). 'No one asks for a meal they’ve never eaten.' Or, do African farmers want genetically modified crops? Agriculture and Human Values, 31(4), 643-648.

Shackford, S. (2014, September 5). Cornell University gets \$5.6 million grant to promote science-based debate. Cornell Chronicle. Retrieved from http://www.news.cornell.edu/stories/2014/08/new-cornell-alliance-science-gets-56-milliongrant

Stone, G. D., \& Flachs, A. (2014). The problem with the farmer's voice. Agriculture and Human Values, 1-5.

Wambungu, F., \& Kamanga, D. (2014). Biotechnology in Africa: Emergence, initiatives, and future. London: Springer. 
Witt, H., Patel, R., \& Schnurr, M.A. (2006). Can the poor help genetically modified crops? Technology, representation, and cotton in the Makhathini Flats, South Africa. Review of African Political Economy, 33, 497-513. 